\title{
Giant eccrine acrospiroma: A case report and review of the literature
}

\author{
Uður Koçer MD ${ }^{1}$, Hasan Mete Aksoy MD ${ }^{1}$, Yiðit Özer Tiftikciođlu MD¹, Dilek Ertoy MD², Önder Karaastan MD ${ }^{1}$
}

\begin{abstract}
U Koçer, HM A ksoy, YÖ Tiftikciođ̆lu, D Ertoy, Ö Karaaslan. Giant eccrine acrospiroma: A case report and review of the literature. C an J Plast Surg 2003;11(1):43-46.
\end{abstract}

BA C K GR OU N D : A crospiromas are histologically distinct cutaneous tumours of sweat duct origin and usually measure 1 to $2 \mathrm{~cm}$ in size.

OBJECTIVE: We describe a patient with a large benign eccrine acrospiroma.

MET H O D S: C ase report and literature review.

RESULT S: A 50-year-old woman underwent excision of a $5.5 \times 5.0 \mathrm{~cm}$ cystic mass located on the left gluteal region, and the resulting defect was closed by a local flap. A diagnosis of benign eccrine acrospiroma was made after histopathological examination. On histol ogical examination, the lesion was characterized by multilobular dermal masses composed of a biphasic cell population. There was no recurrence five months after the operation.

CONCLUSION: Although eccrine acrospiromas are usually benign, they can, on rare occasions, undergo malignant tran sformation. In addition, the clinical appearance of this lesion is not specific and differential diagnosis from other lesions, both benign and malignant, can only be done after the complete removal of the lesion.

\section{A crospirome eccrine géante : 0 bservation de cas et survol de la littérature}

REN SEIG N EMEN TS GÉNÉRAUX : Les acrospiromes sont des tumeurs cutanées en rapport avec le conduit sudorifère, histologiquement distinctes et mesurant habituellement entre 1 et $2 \mathrm{~cm}$.

OBJECTIF : Nous décrivons le cas d'une patiente présentant une acrospirome eccrine bénigne étendue.

MÉTH ODOLOG IE : O bservation de cas et survol de la littérature RÉ SU LTAT S : U ne femme de 50 ans a subi I'ablation d'une masse kystique de 4,5'4,0 cm siégeant dans la région fessière; le vide occasionné par I'ablation du kyste a été comblé au moyen d'un lambeau local. Un diagnostic d'acrospirome eccrine bénigne a été posé après examen histologique. Cet examen a également permis de préciser que la lésion était formée d'une masse dermique multilobulée composée d'une population cellulaire biphasique. On n'a pas observé de récidive cinq mois après I'opération.

CON CLU SION : Bien que les acrospiromes eccrines soient habituellement bénignes, elles peuvent, quoique rarement, subir une transformation maligne. En outre, il s'agit d'une lésion ne présentant aucun caractère clinique spécifique de sorte que la distinction avec d'autres lésions, bénignes ou malignes, ne peut être faite qu'après excision complète de la lésion.

Key Words: A crospiroma; M alignant transformation; M inor trauma

n 1969, Johnson and Helwig (1) introduced the term 'eccrine acrospiroma' to define a cutaneous neoplasm that had been previously reported under a variety of terms. This lesion was considered to be related to the epithelial cells of eccrine sweat ducts (1). O ther synonyms of eccrine acrospiroma are clear cell, nodular, superficial or solid-cystic hidradenoma; clear cell papillary carcinoma; clear cell myoepithelioma; porosyringoma; large cell sweat gland adenoma; or basal cell carcinoma of sweat gland origin (2). These tumours occur typically as small $(1$ to $2 \mathrm{~cm}$ ) incidental solid to cystic lesions of the skin, but they may al so attain sizable proportions. They affect all age ranges and involve any area of the body, and the majority of them are benign (3). $M$ alignant forms of this tumour do exist and malignant transformation of a pre-existing benign eccrine acrospiroma has been reported (3). In the present article, we report the clinical and histopathological features of a large, benign eccrine acrospiroma located on the left gluteal region in a 50-year-old woman.

\section{CASE PRESEN TATION}

A 50-year-old woman was evaluated for an enlarging swelling on the left gluteal region. It had gradually increased in size over one year, and, very interestingly, it had followed an intramuscular injection according to the history obtained from the patient. It was learned that the mother of the patient had died of stomach cancer. On physical examination, a single, nontender, $5.5 \times 5.0 \mathrm{~cm}$ reddish-blue cystic mass was noted on the left gluteal region (Figure 1). A computed tomography of the lesion revealed a mass with both cystic and solid components extending some distance into the superficial fascia without involving the deep fascia. Full blood count, liver and kidney function tests, and chest $\mathrm{x}$-ray were all normal. $\mathrm{U}$ rine analysis revealed the presence of abundant leucocytes in the urine. Because the clinical appearance of the lesion did not preclude a primary or metastatic malignancy, an abdominopelvic ultra-

This case was presented as an oral presentation at the 2nd Balkan C ongress of Plastic Reconstructive and A esthetic Surgery, M ay 26, 2001, Belgrade, Yugoslavia

1Plastic and Reconstructive Surgery D epartment, A nkara Training and Research H ospital; ${ }^{2} \mathrm{D}$ epartment of Pathology, $\mathrm{H}$ acettepe U niversity School of M edicine, A nkara, Turkey

Correspondence: Dr U đur K oçer, M esrutiyet C ad. 17/12 06640 Kizilay, A nkara, Turkey. Telephone +90-312-4175535,

fax+90-312-4255633, e-mail u.kocer@yahoo.com 


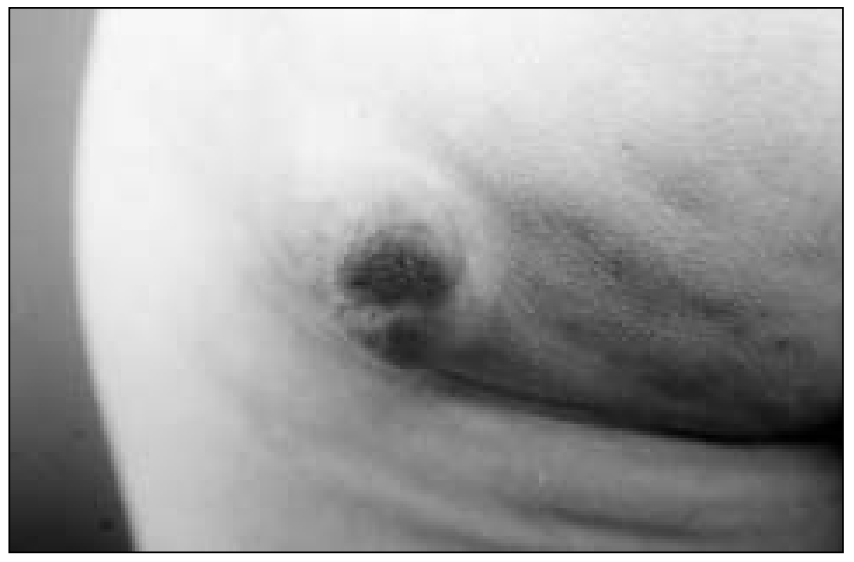

Figure 1) A large cystic mass located on the left gluteal region

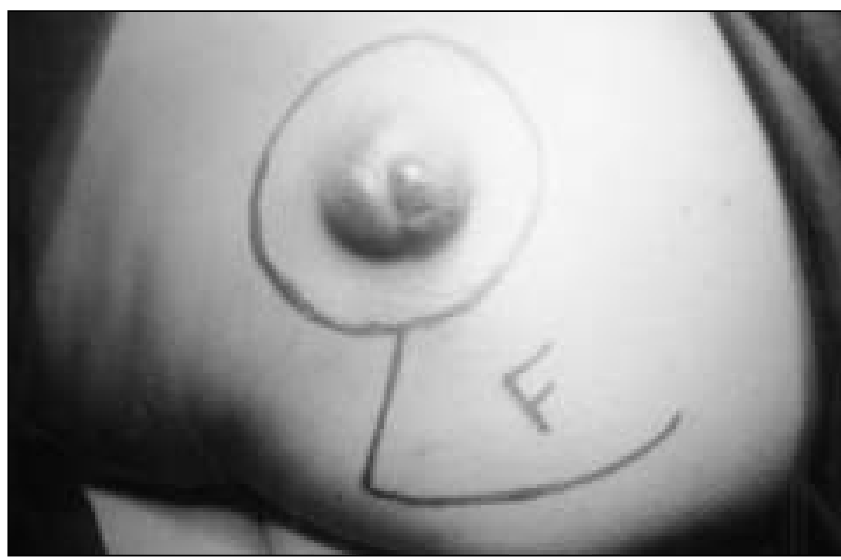

Figure 2) Excision margins and the planning of the flap

sonography was also performed, and no metastatic or primary tumour was detected. 0 floxacine was given to the patient for one week to decrease the risks of a urinary tract infection associated with general anesthesia.

The lesion was excised with a surgical margin of $2 \mathrm{~cm}$, together with the superficial and deep fascia, and the resulting defect was closed by a transposition flap under general anesthesia (Figure 2). This kind of excision was chosen due to the fact that the biological behaviour of the lesion could not be predicted from its clinical appearance and radiological studies. There were no complications related to surgical treatment. $\mathrm{H}$ istopathological examination of the specimen was consistent with acrospiroma. A fter four months, there was no evidence of local recurrence (Figure 3).

\section{PAT H OLOG Y}

Macroscopically, the lesion was a well circumscribed, but unencapsulated, partially cystic nodule (Figure 4). C ysts contained watery fluid and papillary excrescencies inside.

Microscopic examination showed a typical acrospiroma, a benign cutaneous tumour of eccrine gland origin. It was situated in the dermis extending into the subcutaneous tissue (Figure 5, top). T he overlying epidermis was un remarkable and had no connection with the lesion. The tumour was largely cystic. The cysts were lined by multiple cell layers and contained many papillae projecting toward the lumen (Figure 5,

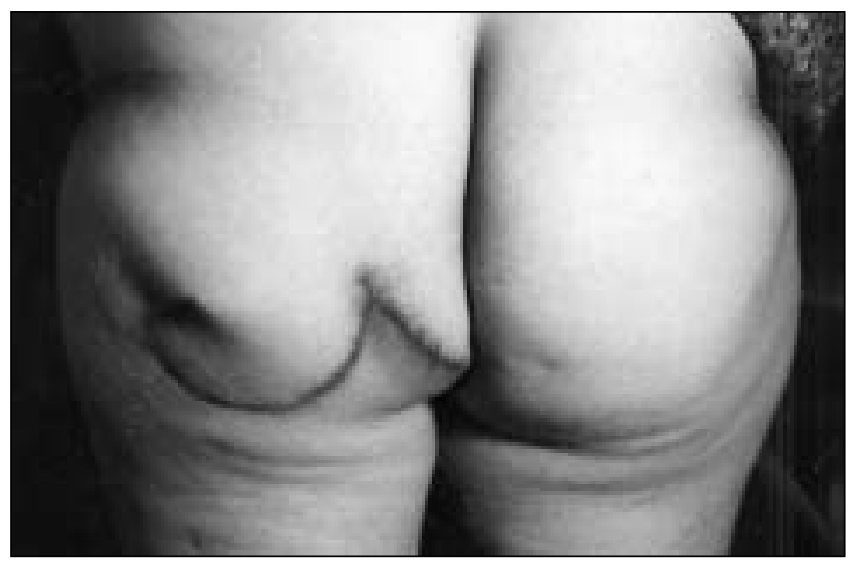

Figure 3) Postoperative appearance five months later

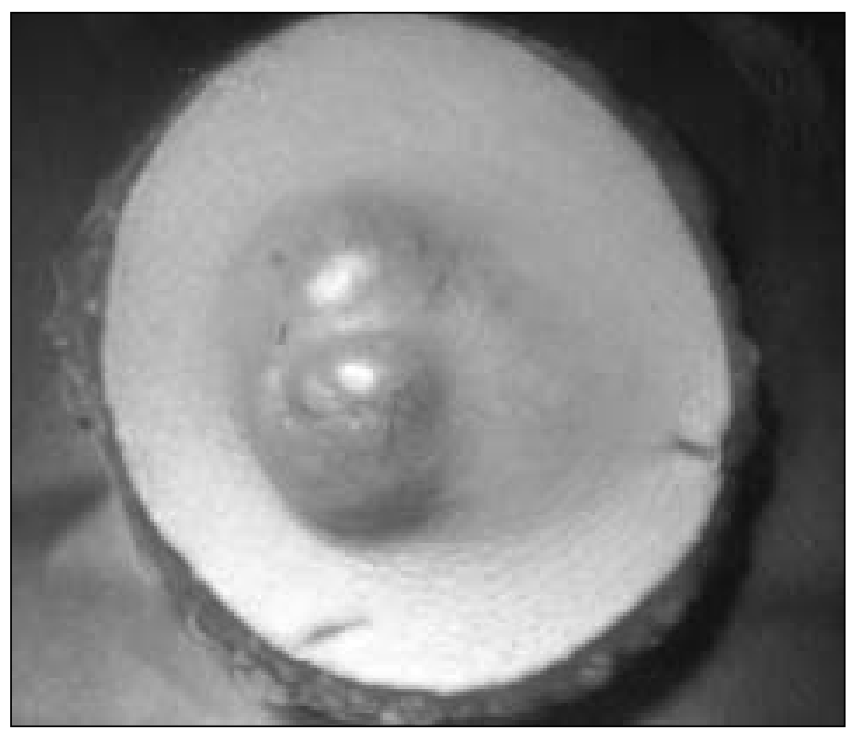

Figure 4) M acroscopical appearance of the lesion

bottom). The neoplasm consisted of a biphasic cell population - eosinophilic and clear cells. Intermediate-sized squamoid cells having eosinophilic cytoplasm were the predominating cell type (Figure 6, top). They had oval regular nuclei and finely granular chromatin, and were arranged into solid masses or papillary structures inside the cyst cavities. Cells in the centre of solid lobules showed a tendency to be aggregated in a concentric fashion (Figure 6, bottom). Keratinization was not observed. Clear cells characterized by abundant cytoplasm, centrally located nuclei and distinct cell borders were detected infrequently. They formed tubular structures simulating eccrine duct formation (Figure 7). The neoplasm lacked cellular atypia, necrosis, perineural invasion or lymphovascular invasion. M itotic figures were rare (less than $1 / 5$ high power fields).

\section{DISC U SSION}

A crospiroma occurs as a single nodular, solid or cystic, occasionally elevated cutaneous mass. A s a rule, the skin over the tumour is either flesh-coloured, red or blue, and is smooth, but sometimes it is thickened and papillary (4). The tumours vary in size from 0.5 to $10 \mathrm{~cm}$, but most measure from 1 to $2 \mathrm{~cm}$ and 

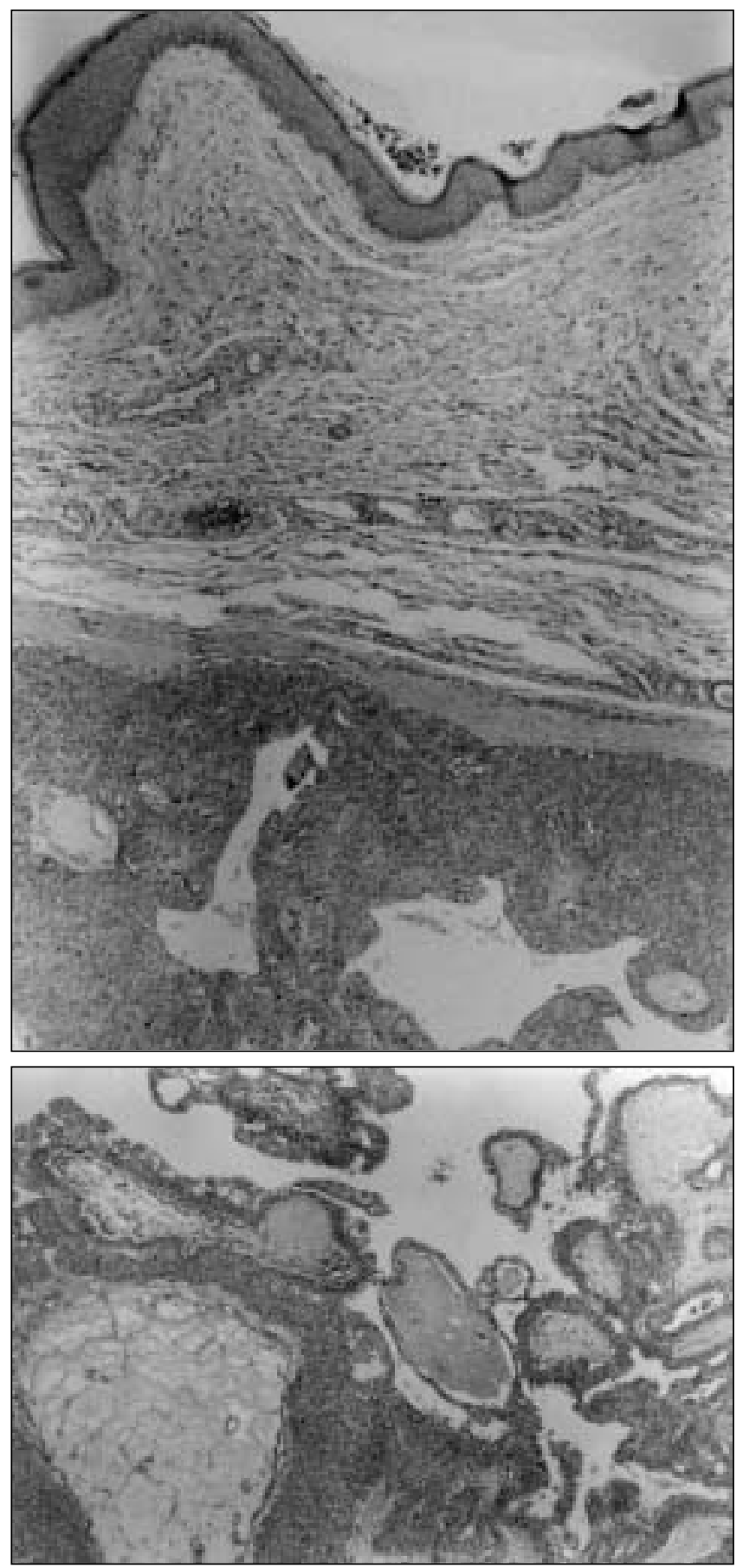

Figure 5) Tumour localized in the lower dermis, consisting of both solid and cystic areas. Top Epidermis was not invaded by the tumour; Bottom $\mathrm{N}$ umerous papillae projecting into cyst lumen (hematoxylin and eosin stain, original magnification $\times 40$ )

the median size of eccrine acrospiromas is only $1 \mathrm{~cm}(3,4)$. $\mathrm{G}$ iant lesions are rare, but examples of such include a $12 \mathrm{~cm}$ tumour of the left thigh and a tumour of similar size on the dorsum of the left hand (3). It was mentioned in the literature that longstanding tumours may grow to be larger than $10 \mathrm{~cm}$, yet still be benign (3). In one study, four tumours (out of 38 total tumours) with diameters of more than $4 \mathrm{~cm}$ were accepted as tumours of 'large size' (5). In a report of three cases of benign giant eccrine acrospiroma, the smallest lesion was
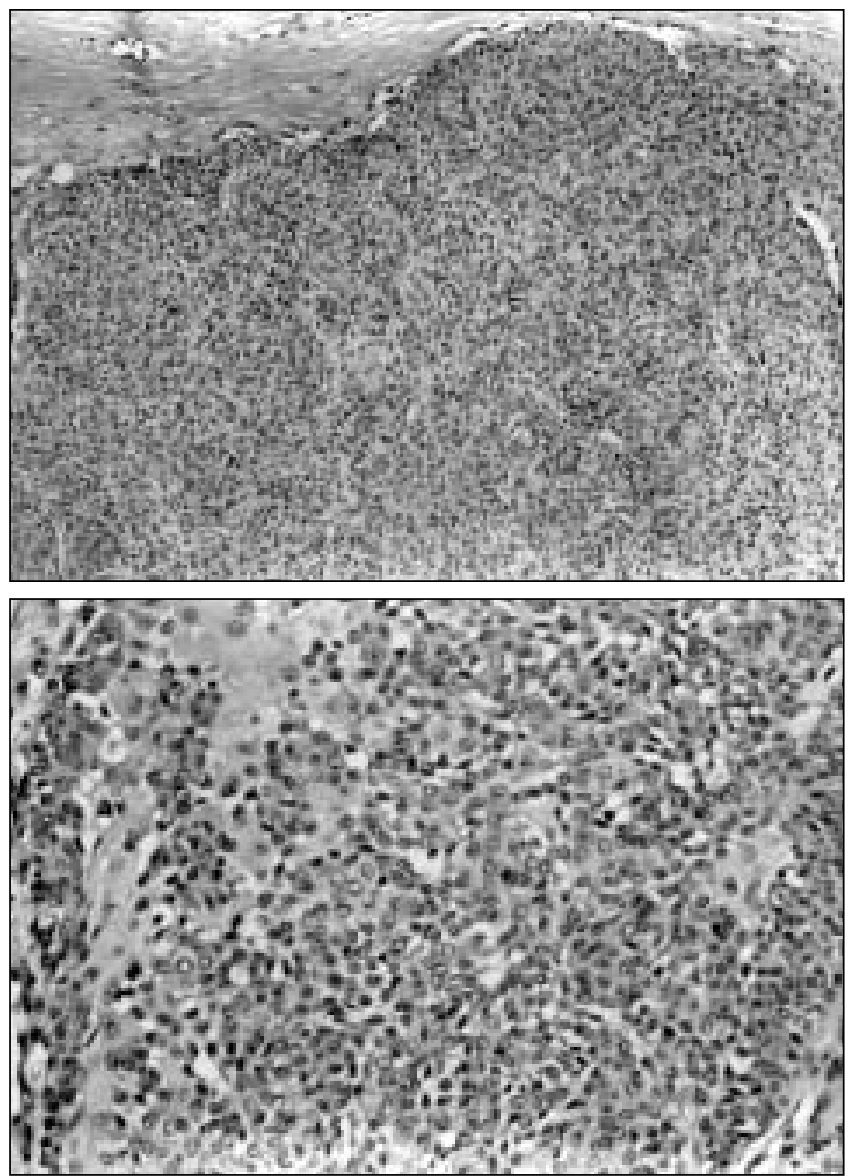

Figure 6) A solid area formed by intermediate-sized squamoid cells that had a vague tendency to gather in small concentric aggregates without keratinization. Clear cells were rarely seen between eosinophilic cells. Top H ematoxylin and eosin stain, original magnification $\times 100$; B ottom $\mathrm{H}$ ematoxylin and eosin stain, original magnification $\times 200$

$5 \times 3 \mathrm{~cm}$ in size and the largest one was $9.5 \mathrm{~cm}$ in its largest dimension (3). It is interesting that the lesion in our patient attained a large size in a relatively short period of time. Large eccrine acrospiromas may foster concerns of malignancy, but malignant eccrine acrospiromas are rare and are usually of moderate size. In a review of the literature, the largest dimension specified for malignant acrospiromas ranged from 4 to $10 \mathrm{~cm}(3,6)$. Thus, size cannot be used to differentiate between benign and malignant acrospiromas.

A crospiromas occur on all areas of the body, but are slightly more common on the trunk $(40 \%)$, followed by the head $(30 \%)$ and extremities $(30 \%)(1,7,8)$. A crospiromas predominate in women by a ratio of approximately $2: 1$ and occur more commonly in middle-aged and older adults, with a range of three to 93 years (1). A pproximately one-sixth of the lesions show drainage, and about the same number are painful (4). There is also an occasional association of pruritis (7\%) with these lesions (2). The clinical differential diagnosis consists of hemangioma, squamous cell carcinoma, melanoma, metastatic tumours and other adnexal tumours (2).

Reports have shown an association between the sudden appearance of this lesion and minor trauma (1). In the present case, we observed the sudden appearance of the eccrine 

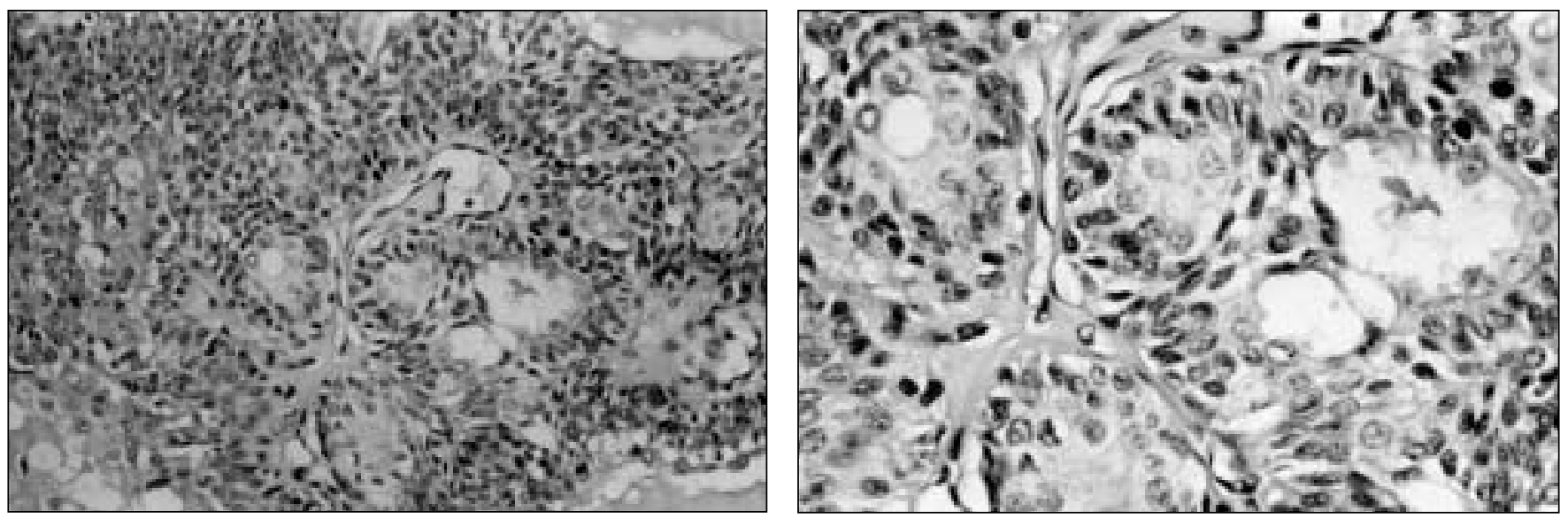

Figure 7) Ductal differentiation. Duct-like structures lined by single layer of cuboidal cells with large amounts of clear cytoplasm. L eft $\mathrm{H}$ ematoxylin and eosin stain, original magnification $\times 200$; $\mathbf{R}$ ight $\mathrm{H}$ ematoxylin and eosin stain, original magnification $\times 400$

acrospriroma following an intramuscular injection. Thus, trauma seems to play a role in the etiology of this lesion.

In contrast to its relatively more common counterpart, malignant acrospiromas are highly invasive, often with significant lymphatic and distant metastasis $(6,9)$. The establishment of this diagnosis is difficult on both clinical and histopathological grounds (9). The malignant version of eccrine acrospiroma shows cellular atypia, frequent mitoses, infiltrative local growth, areas of necrosis, perineural invasion and angiolymphatic invasion $(3,6)$. M oreover, malignant transformation of benign eccrine acrospiromas has been reported (3). M alignant acrospiromas tend to be predominantly solid, without the grossly cystic nature that seems to be largely responsible for the production of the giant benign tumours (3).

Treatment for benign acrospiromas consists of surgical excision. In a series of 319 tumours that included five malignant lesions, there were 38 recurrences after surgical excision and the recurrent tumours were neither more aggressive nor more atypical than the primaries, and differed only in their location, which was deeper in the dermis (1). Inadequate excision was considered to be the major cause of recurrence (1). In addition to wide local excision, regional lymph node dissection is recommended after the diagnosis of malignant acrospiroma, even in the face of a clinically negative lymph node examination
(6). In our case, we preferred wide local excision to a more limited excision because we could not be certain about the biological behaviour of the lesion. Thus, the prognosis for benign acrospiroma is good and this type of lesion is not associated with recurrence when adequately excised.

\section{REFEREN CES}

1. Johnson BL Jr, H elwig EB. Eccrine acrospiroma: A clinicopathologic study. Cancer 1969;23:641-57.

2. Laws RA, English JC 3rd, Elston DM. A crospiroma: A case report and review. Cutis 1996:58:349-51.

3. H unt SJ, Santa Cruz DJ, Kerl H. G iant eccrine acrospiroma. A m A cad Dermatol 1990;23:663-8.

4. Helwig EB. Eccrine acrospiroma. J Cutan Pathol 1984;11:415-20.

5. Keasby LE, H adley G G. C lear cell hidradenoma: Report of three cases with widespread metastases. C ancer 1954;7:934-51.

6. Headington JT, N iederhuber JE, Beals TF. M alignant clear cell acrospiroma. Cancer 1978:41:641-7.

7. Cohen PR, Tschen JA . A painless enlarging scalp nodule: Eccrine acrospioma. A rch Dermatol 1992;128:547-50.

8. G rossniklaus HE, Knight $\mathrm{SH}$. Eccrine acrospiroma (clear cell hidradenoma) of the eyelid: Immunohistochemical and ultrastructural features. O pthalmology 1991;98:347-52.

9. Long W P, Dupin C, Levine EA . Recurrent malignant acrospiroma: treatment by chest wall excision. Dermatol Surg 1998;24:908-12. 